\title{
Trudności w wyznaczaniu osuwisk na obszarach historycznych i zurbanizowanych na przykladzie Twierdzy Przemyśl
}

\author{
Edyta Rycio ${ }^{1}$
}

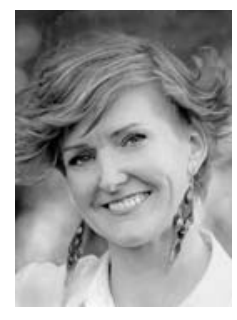

Difficulties in determining landslides in historical and urbanized areas - a case study of the Przemyśl Fortress. Prz. Geol., 68: 902-914; doi: 10.7306/2020.39

A b s tr a c t. The Przemysil Fortress is a huge complex of defensive objects from the turn of the $19^{\text {th }}$ and $20^{\text {th }}$ centuries. Various types of objects, ruins and remains of the fortress and signs of fights have been preserved to different extents in the area to this day. They constitute a huge problem when determining landslides. The greatest difficulties are caused by vegetation-covered ruins of forts, trenches, remnants of ramparts and defense ditches, and signs of fights preserved in places. Such residues can be interpreted as a landslide or a part of it, especially if they occur in a neighbourhood or inside a landslide. The problem then arises of clearly identifying the boundaries of the landslide and the correct identification of its internal forms, e.g. a devastated trench around the fort can be marked as a landslide. Similar difficulties are provided by numerous inactive quarries, excavations, clay pits, e.g. a closed limestone open-pit mine from the $19^{\text {th }}$ century, located in Kruhel Wielki. Elements of the old mine are deceptively reminiscent of intra-field forms and they are difficult to separate from the real colluvial forms of the neighbouring landslide. Difficulties in determining landslides arise not only from the history of this region and its geological structure, but also from the degree of urbanization of the area. Strong anthropopression blurs the natural morphology of the slopes, and the limited availability of the area makes cartographic work difficult. It is difficult to distinguish between natural and artificial forms in such areas. Good examples are landslides on the ski slope, on the municipal cemetery, in the castle park and in the area of military areas, housing estates and allotments.

Keywords: the Przemyśl Fortress, ruins of forts, quarry, landslides, anthropopression, NMT (DTM)

Twierdza Przemyśl na początku XX w. była trzecią co do wielkości twierdzą w Europie (po Antwerpii w Belgii i Verdun we Francji) oraz jedną z 200 wielkich fortyfikacji stałych istniejących w Europie. Porównywano ją wówczas $\mathrm{z}$ francuską twierdzą Verdun, określając Przemyśl mianem Verdun wschodniego frontu. Podczas I wojny światowej walczyli tu między innymi Austriacy, Węgrzy, Rosjanie, Niemcy, Czesi, Polacy i Włosi.

Decyzję o budowie twierdzy podjęto w $1871 \mathrm{r}$. w sztabie głównym armii austro-węgierskiej. Pogarszające się stosunki między Austrią i Rosją, w szczególności po wojnie krymskiej, wymusiły rozpoczęcie fortyfikacji austriackich miast. Przemyśl był wtedy małym 10-tysięcznym miasteczkiem i choć nie był głównym kandydatem do budowy twierdzy, która miała zaważyć na losach cesarstwa, to właśnie Przemyśl został wybrany do ufortyfkowania, najpierw przez majora sztabu generalnego, a następnie arcyksięcia Karola (Rożański, 1983; Idzikowski, 2014). Atutem Przemyśla okazało się jego położenie nad Sanem, pośród wzgórz Pogórza Przemysko-Dynowskiego. Głównym celem budowanej twierdzy miała być obrona Bramy Przemyskiej na styku Kotliny Sandomierskiej i Karpat, którą wiódł szlak handlowy z Polski i Rusi na Węgry. Jej znaczenie dodatkowo wzrosło, gdy pod koniec XIX w. Przemyśl stał się ważnym węzłem kolejowym i drogowym na trasie z Wiednia do Lwowa.

Budowa samej twierdzy trwała od 1874-1914 r., a ze względów finansowych nigdy nie ukończono w pełni projektu budowy. Długi okres budowy sprawił, że charakteryzuje się ona dużą różnorodnością budowli fortyfikacyjnych.
Znajdują się tutaj przestarzałe szańce artyleryjskie, jednoi dwuwałowe forty artyleryjskie oraz nowoczesne forty pancerne i opancerzone z przełomu stulecia. Te przeobrażenia sztuki fortyfikacyjnej były następstwem rozwoju techniki w tym okresie i ukazuja przekrój austriackiej sztuki obronnej. Twierdza Przemyśl składała się z dwóch pierścieni fortyfikacji okalających miasto (ryc. 1). Pierścień zewnętrzny był zbudowany na 17 wzgórzach i liczył $45 \mathrm{~km}$ obwodu, 12-15 km średnicy i składał się z 15 fortów głównych, 25 pomocniczych i 5 wspierających. Ponadto wybudowano 14 stałych działobitni, 2 stałe linie okopów i 2 stałe bazy dla piechoty. Wewnętrzny pierścień obronny składał się z 21 fortów obronnych zlokalizowanych najbliżej miasta, miał $20 \mathrm{~km}$ obwodu i 3-5 km średnicy. Dodatkowym zabezpieczeniem twierdzy były zasieki, pola minowe i rowy przeciwpiechotne.

Do dzisiaj w różnym stopniu zachowały się pozostałości po twierdzy, które w znacznie utrudniają prace kartograficzne, zwłaszcza niedoświadczonym badaczom.

Twierdza Przemyśl w całości znajduje się na obszarze miejsko-wiejskiej gminy Przemyśl, położonej w południowo-wschodniej części województwa podkarpackiego na Pogórzu Przemysko-Dynowskim. W latach 2012-2013 na obszarze miasta i gminy Przemyśl były prowadzone prace kartograficzne w ramach Projektu System Osłony Przeciwosuwiskowej (SOPO). Celem niniejszego artykułu jest wskazanie trudności, jakie można napotkać podczas prac kartograficznych prowadzonych na terenach silnie przekształconych historycznie i antropogenicznie. Uniknięcie błędów interpretacyjnych wymaga dużego doświadczenia

\footnotetext{
${ }^{1}$ Państwowy Instytut Geologiczny - Państwowy Instytut Badawczy, Centrum Geozagrożeń, ul. Skrzatów 1, 31-560 Kraków; rycio.edyta@pgi.gov.pl
} 


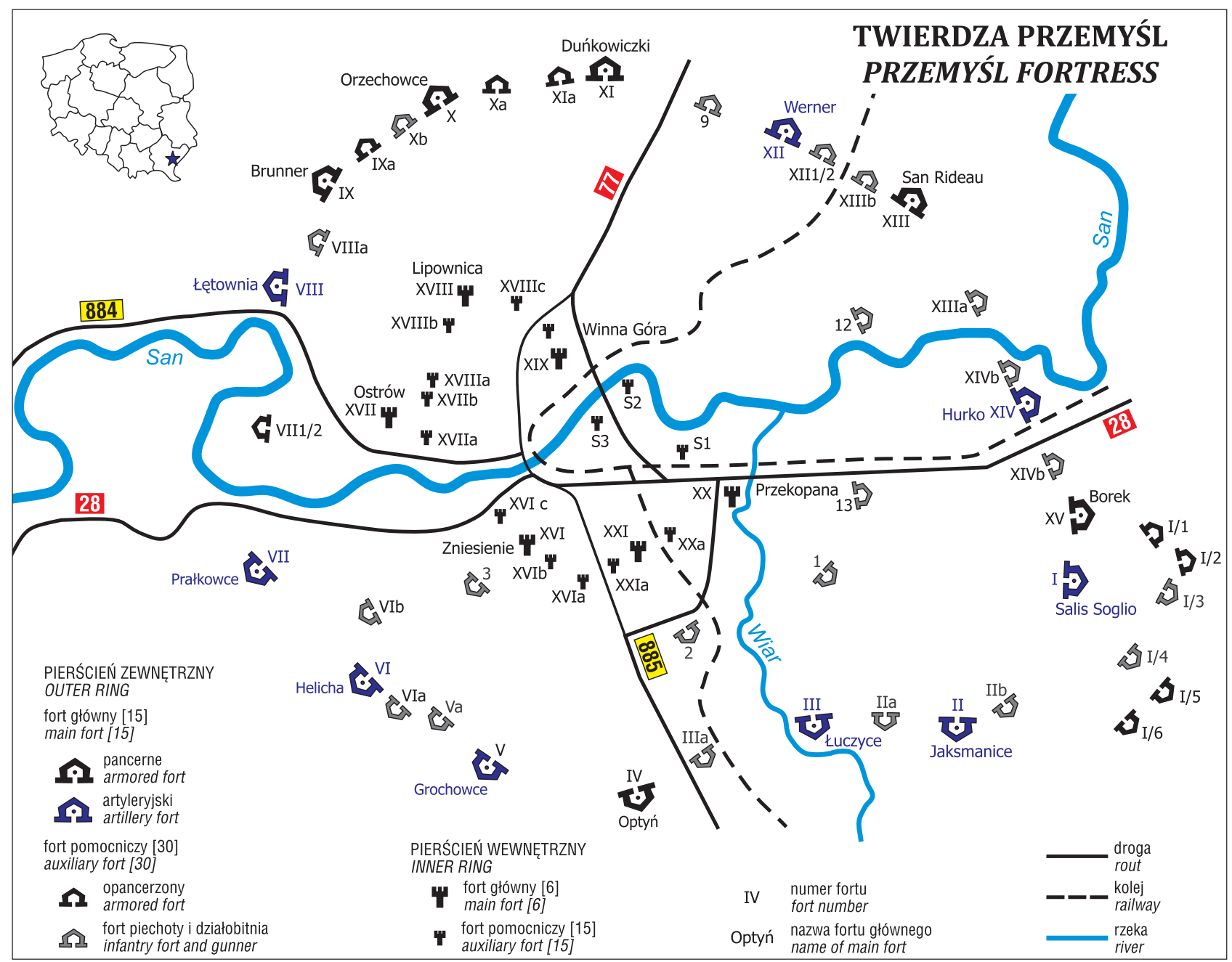

Ryc. 1. Szkic lokalizacyjny i schemat Twierdzy Przemyśl (za: Rożańskim, 1983; Idzikowskim, 2008, 2014)

Fig. 1. Location sketch and construction scheme of the Przemyśl Fortress (after: Rożański, 1983; Idzikowski, 2008, 2014)

i uwagi. W tekście zostaną zasygnalizowane przesłanki i wskazówki mogące pomóc uniknąć błędów kartograficznych, które wbrew pozorom często mają miejsce.

\section{HISTORIA BADAŃ}

W literaturze dotyczącej omawianego obszaru dużo miejsca poświęcono badaniom stratygrafii oraz geologii i tektoniki okolic Przemyśla (Wiśniowski, 1918; Rogala, 1921; Rogala, Kokoszyńska, 1948; Strzępka, 1975; Skompski, 1990 i in.), zwłaszcza nasunięciu brzeżnemu Karpat na miocen Zapadliska Przedkarpackiego (Niedźwiedzki, 1901, 1910; Ney, 1957a; Wilczyński, 1961; Gucik, 1962, 1963, 1977, 1986c; Zieliński, 1963; Głowacki, 1964; Aleksandrowicz, 1965; Głowacki i in., 1966; Jucha, 1968; Garlicki, 1973; Połtowicz i in., 1974; Gucik, Wójcik, 1980; Żytko, 1986; Połtowicz, 1991; Krzywiec, Pietsch, 1996; Malata, 1996; Garecka, Olszewska, 1997; Kuśmierek, Baran, 2008 i wielu innych badaczy). Duża część publikacji była związana z poszukiwaniem węglowodorów (Głowacki, Karnkowski, 1964; Jabłońska, Drwiła, 1968; Karnkowski, 1997 i in.). Szczególnym zainteresowaniem cieszyły się wapienie z Kruhela Wielkiego (Wójcik, 1904, 1907, 1913; Niedźwiedzki, 1908; Zuber, 1909; Bukowy,
Geroch, 1957; Ney, 1957b; Morycowa, 1964, 1979, 1988, 2008; Geroch, Morycowa, 1966; Liszka, Geroch, 1979; Geroch i in., 1988; Olszewska, 2009).

Natomiast jeśli chodzi o tematykę osuwiskowa, to był to obszar słabo rozpoznany, a Mapa osuwisk i terenów zagrożonych $w$ skali 1:10 000 (MOTZ), która powstała w ramach projektu SOPO, jest pierwszą publikacją w całości opisująca problematykę występowania osuwisk w rejonie miasta i twierdzy Przemyśl (Rycio, Cybulska, 2013a, b, c, d). Pierwsze wzmianki na temat osuwisk omawianego obszaru pojawiają się w tzw. katalogach osuwisk (Chowaniec $\mathrm{i}$ in., 1975), pracach Bobera $(1985,1990)$ i Ziętary (1991). Kolejne formy osuwiskowe zostały udokumentowane w latach 2007-2009 podczas prac prowadzonych nad arkuszem SMGP Przemyśl (Wójcik, Rączkowski, 2018). W 2011 r. na zlecenie Urzędu Miejskiego została wykonana Mapa morfologiczna miasta Przemyśla (Nowak, 2011), która uwzględniała osuwiska, choć nie wszystkie zostały poprawnie wyznaczone, a wiele $\mathrm{z}$ nich nie zostało udokumentowanych.

Bogata jest również literatura dotycząca samej Twierdzy Przemyśl, która jest obiektem zainteresowania miłośników militariów, historii i turystyki (Rożański, 1983, 2000; Wieliczko, 1992; Forstner, 2000; Burzyńska, 2020; Bator, 2005; Idzikowski, 2008, 2014 i wielu innych). 
Tab. 1. Profil litologiczno-stratygraficzny jednostek budujących podłoże w okolicy Przemyśla

Table 1. Lithology and stratigraphy profile of the subsoil-building units in the vicinity of Przemyśl

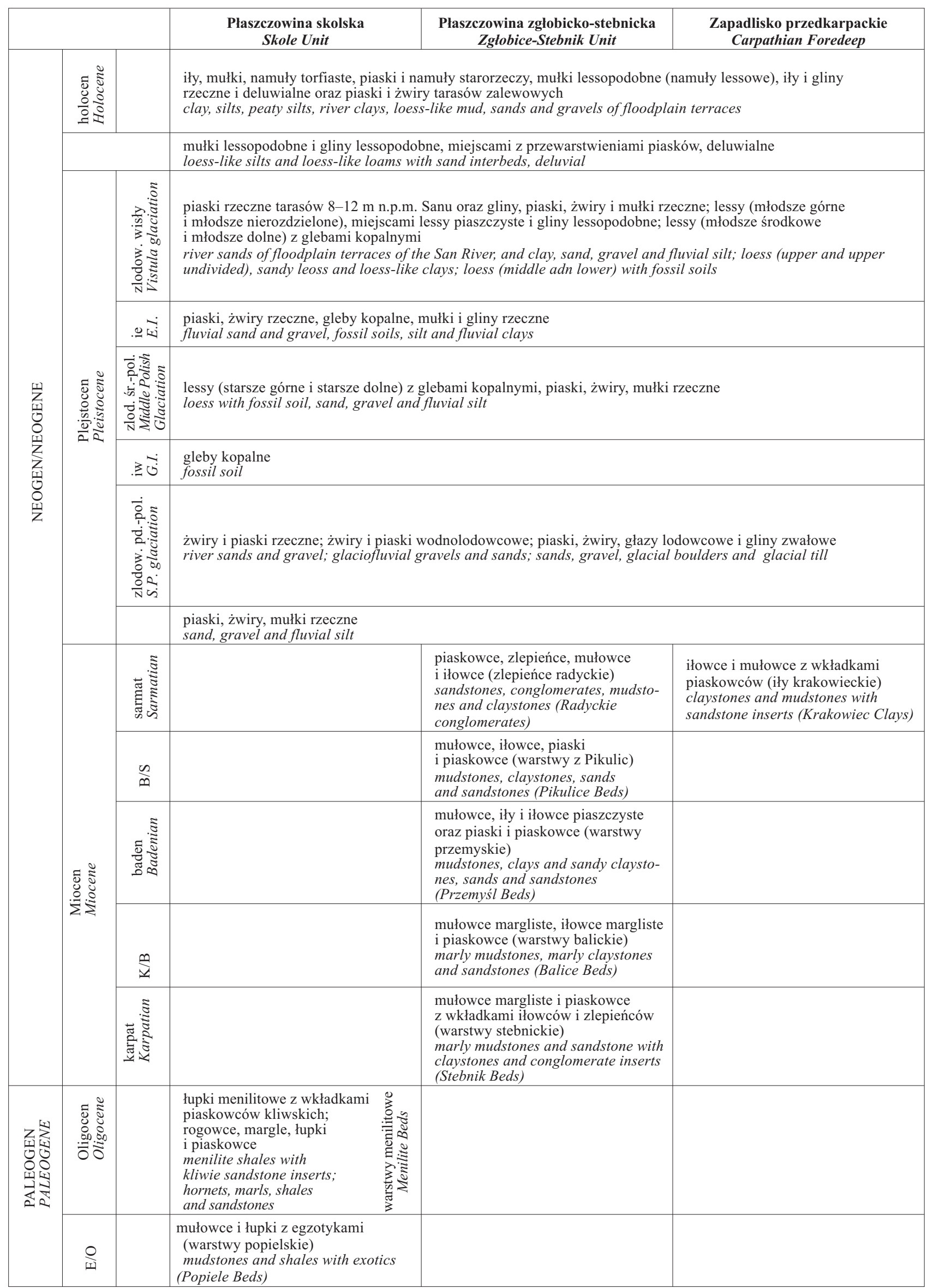


Tab. 1. Profil litologiczno-stratygraficzny jednostek budujących podłoże w okolicy Przemyśla (cd.)

Table 1. Lithology and stratigraphy profile of the subsoil-building units in the vicinity of Przemyśl (cont.)

\begin{tabular}{|c|c|c|c|c|}
\hline & & $\begin{array}{c}\text { Plaszczowina skolska } \\
\text { Skole Unit }\end{array}$ & $\begin{array}{c}\text { Plaszczowina zglobicko-stebnicka } \\
\text { Zglobice-Stebnik Unit }\end{array}$ & $\begin{array}{l}\text { Zapadlisko przedkarpackie } \\
\text { Carpathian Foredeep }\end{array}$ \\
\hline 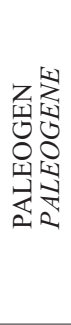 & 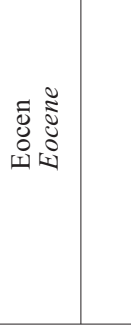 & $\begin{array}{l}\text { łupki i piaskowce oraz łupki } \\
\text { czerwone i zielone (łupki pstre } \\
\mathrm{i} \\
\text { warstwy hieroglifowe); } \\
\text { łupki ilaste czerwone i zielone } \\
\text { oraz piaskowce (łupki pstre) } \\
\text { shales and sandstones with red } \\
\text { and green shales (Variegated Shales } \\
\text { and Hieroglyphic Beds); red and } \\
\text { green clay shales and sandstones } \\
\text { (Variegated Shales) }\end{array}$ & & \\
\hline \multicolumn{2}{|r|}{ 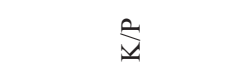 } & $\begin{array}{l}\text { piaskowce i hupki } \\
\text { sandstones and shales }\end{array}$ & & \\
\hline \multirow{2}{*}{ 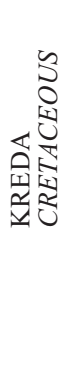 } & 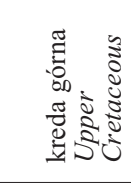 & 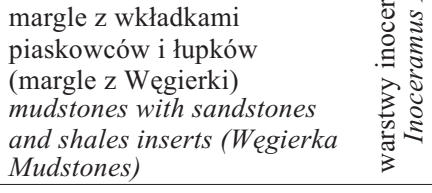 & & \\
\hline & 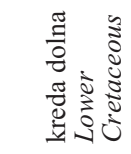 & $\begin{array}{l}\text { łupki czarne (łupki spaskie) } \\
\text { black shales (Spaskie Shales) }\end{array}$ & & \\
\hline
\end{tabular}

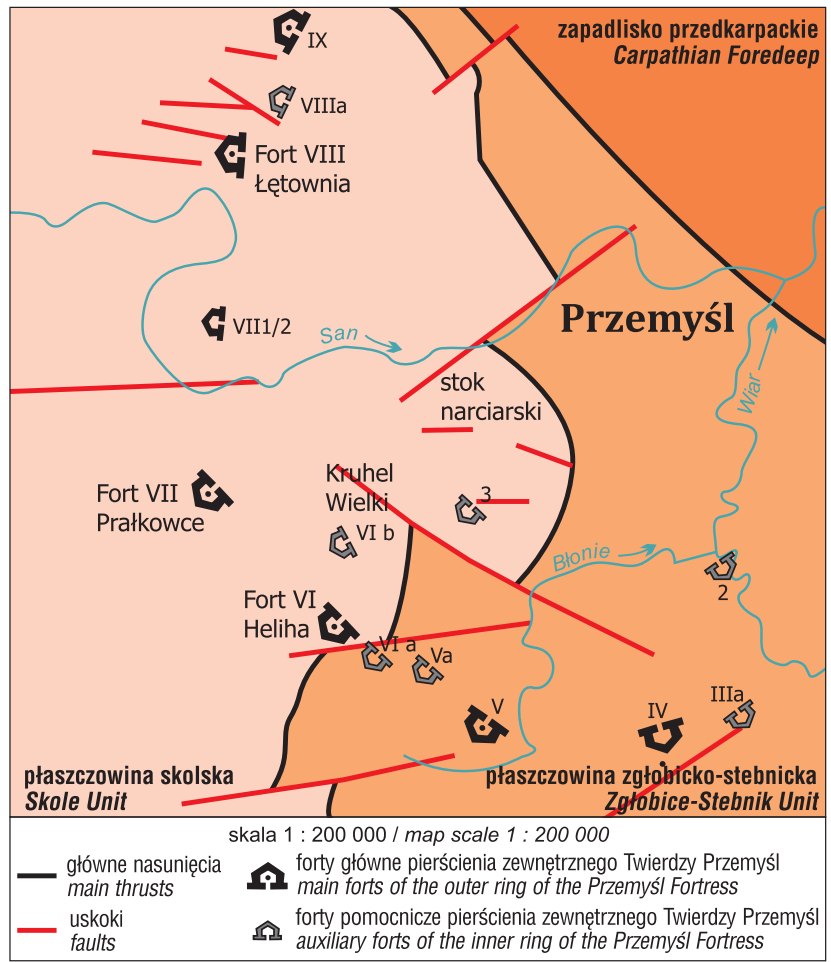

Ryc. 2. Uproszczony szkic tektoniczny terenu badań

Fig. 2. Simplified tectonic sketch of the research area

\section{BUDOWA GEOLOGICZNA}

Twierdza, gmina i miasto Przemyśl znajdują się na pograniczu Karpat i zapadliska przedkarpackiego (Książkiewicz, 1972; Oszczypko, 2001, 2006). Nasunięcie brzeżne Karpat jest położone kilka kilometrów na wschód od doliny rzeki Wiar i łukiem ciągnie się ku północy. Głębokie podłoże jest zbudowane $\mathrm{z}$ utworów jednostki skolskiej i zgłobicko-stebnickiej oraz miocenu zapadliska przedkar- packiego (Wójcik, Rączkowski, 2018). Utwory te praktycznie na całej powierzchni omawianego obszaru sa przykryte miąższymi pokładami lessów, glin lessopodobnych oraz osadami rzecznymi doliny Sanu i Wiaru (Maruszczak, 1988; Łanczot, 1993, 1997; Wójcik, Rączkowski, 2018).

Syntetyczny i uproszczony profil litologiczno-stratygraficzny utworów fliszowych serii skolskiej i zgłobicko-stebnickiej dla okolic Przemyśla wg: Borysławskiego i in. (1979), Gucika i in. (1979), Gucika (1986a, b) oraz Wójcika i Rączkowskiego (2018) zaprezentowano w tabeli 1.

Wszystkie analizowane rejony, które przyspożyły wielu wątpliwości i trudności interpretacyjnych, znajdują się w zachodniej części obszaru twierdzy i miasta Przemyśl (ryc. 2). Podłoże badanego terenu jest zbudowane $\mathrm{z}$ warstw inoceramowych serii skolskiej, które miejscami są pokryte nawet 15-metrowej miąższości lessami i glinami lessopodobnymi. Bardziej szczegółowo budowa geologiczna zostanie opisana podczas analizy przypadku.

\section{TRUDNOŚCI KARTOGRAFICZNE ZWIĄZANE Z TWIERDZĄ PRZEMYŚL}

Mimo że główne forty Twierdzy Przemyśl na ogół budowano na szczytach wzgórz, to w czasie terenowych prac kartograficznych różnorakie pozostałości po twierdzy powodowały trudności w wyznaczeniu przebiegu linii i wysokości skarpy głównej oraz granic osuwiska. Wykonane na górnym stoku fosy, szańce lub nasypy mają często takie usytuowanie i kształt, że mogą być mylnie oznaczone jako rowy rozpadlinowe, szczeliny osuwiskowe, wały akumulacyjne lub skarpy główne.

$\mathrm{Na}$ rycinie 3.1 przedstawiono cyfrowy model terenu wygenerowany za pomocą oprogramowania GlobalMapper z okolic Fortu Łętownia (ryc. 2). Widoczny jest fort na szczycie góry oraz duże osuwiska rozwinięte na jej stokach. Skarpy główne obu osuwisk sięgają praktycznie do wałów wykonanych dookoła fortu. Szczegółowej analizie poddane zostało osuwisko o $\mathrm{nr}$ ID 57073. W tym przypadku 


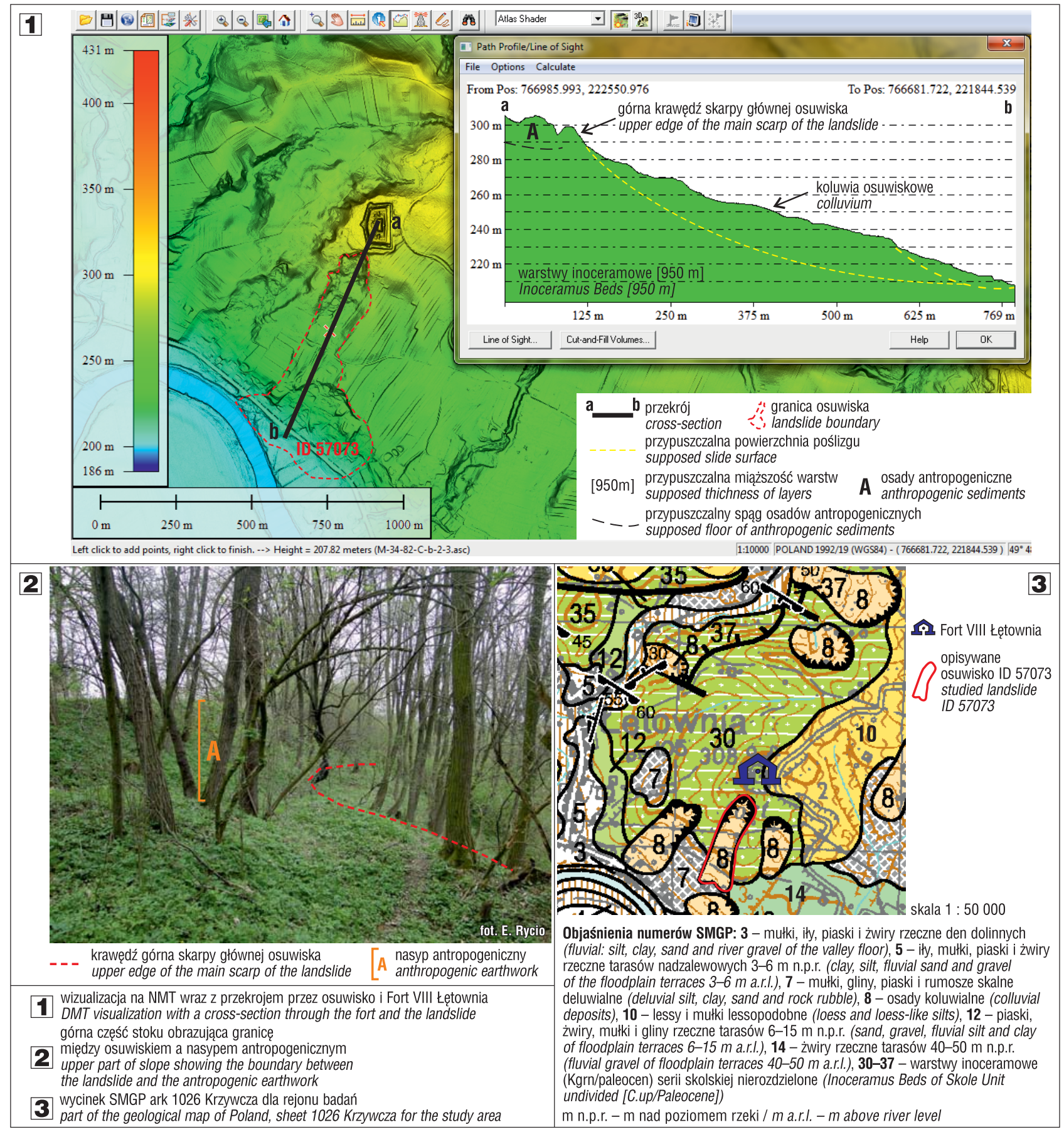

Ryc. 3. Fort VIII Łętownia

Fig. 3. Fort VIII Łętownia

pojawiła się wątpliwość, gdzie przebiega krawędź skarpy głównej osuwiska, a dokąd sięga nasyp antropogeniczny. Przekrój wykonany w programie GlobalMapper przez górną część stoku ze skarpą główną osuwiska i nasypem/wałem fortu przedstawia mało wyraźne podstromienie. Krawędź oddzielająca skarpę osuwiska od nasypu jest bardzo delikatnie zaznaczona na przekroju (ryc. 3.1), a w terenie granica ta jest jeszcze mniej widoczna (ryc. 3.2). W wyniku błędnej identyfikacji położenia górnej krawędzi skarpy głównej kolejnym błędem, który łatwo jest popełnić, jest zły pomiar wysokości i kąta nachylenia skarpy.

Osuwiska rozwinęły się na południowych, południowo-zachodnich i zachodnich zboczach poniżej Fortu Łętownia. Wzgórze to jest zbudowane $\mathrm{z}$ warstw inoceramowych, wykształconych jako piaskowce cienko- i średnioławico- we, łupki z wkładkami margli przewarstwione łupkami pstrymi. Wiek tych warstw określany jest na późną kredęwczesny paleocen, ich miąższość osiaga w tych rejonach $950 \mathrm{~m}$. Pod nimi zostały nawiercone nierozdzielone mioceńskie utwory serii zgłobicko-stebnickiej (Gucik, 1986a, b), wykształcone jako mułowce, iłowce piaszczyste, piaskowce i zlepieńce. Lessy i mułki lessopodobne pokrywająjedynie wschodnie zbocza wzgórza i w dolnych partiach stoków mogą osiagać miąższość nawet $10 \mathrm{~m}$.

Jeszcze większa trudność w rozpoznaniu pojawia się, gdy fort lub/i szańce znajdują się na stoku środkowym, tym bardziej jeśli poniżej na stoku znajdują się osuwiska. Zniszczone i mocno porośnięte roślinnością ruiny fortów wraz z okopami, łukowatymi śladami wałów lub rowów obronnych mogą zostać zinterpretowane jako całe osuwiska 
lub ich fragmenty. Na rycinie 4.1 jest widoczny Numeryczny Model Terenu (NMT) obszaru położonego na wschód od fortu Helicha (znajdującego się na wzgórzu Helicha) z niewielkim, źle zachowanym fortem pomocniczym zbudowanym na stoku środkowym.

Wzgórze Helicha, przechodzące ku północy w Wapielnicę (dawny Lipnik), jest zbudowane $\mathrm{z}$ warstw inoceramowych serii skolskiej. Wykształcone są one na przełomie późnej kredy/paleocenu w postaci piaskowców cienkoi średnioławicowych z łupkami i wkładkami margli oraz łupków pstrych. W ich obrębie występują mułowce z egzotykami i olistolitami wapieni typu sztramberskiego, tzw. skałki z Kruhela (Wójcik, 1904, 1907, 1913; Niedźwiedzki, 1908; Zuber, 1909; Bukowy, Geroch, 1957; Ney, 1957b;
Morycowa, 1964, 1979, 1988, 2008; Geroch, Morycowa, 1966; Liszka, Geroch, 1979; Geroch i in., 1988; Olszewska, 2009). Zachodnie zbocza są pokryte lessami o niewielkich miąższościach w górnych partiach stoków po $10 \mathrm{~m}$ miąższości $\mathrm{w}$ dolnych partiach stoku. Fort pomocniczy został zbudowany w obrębie występujących pokryw lessowych, ale niewykluczone, że jego fundamenty sięgają piaskowców warstw inoceramowych.

W miejscu zniszczonego fortu przez stok wykonano krótki przekrój a-b. Widać, że taki zapełznięty, zniszczony fort w przekroju przypomina osuwisko, z wyraźną skarpą główną, rowem rozpadlinowym, koluwiami, a nawet wyraźnym czołem. Podobnie wygląda to w terenie, gdzie elementy starego fortu przypominają formy wewnętrzne osuwiska

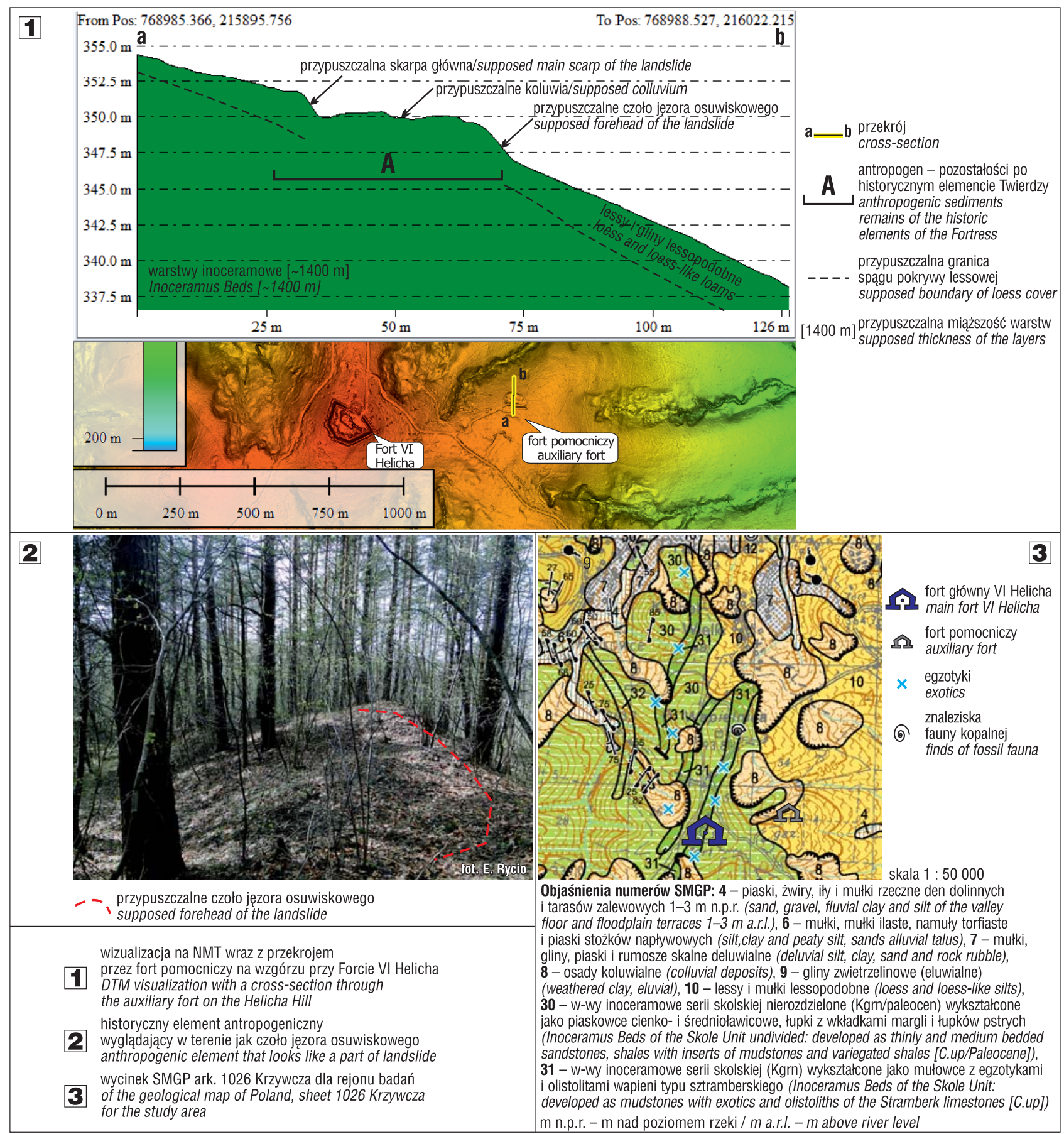

Ryc. 4. Zniszczony fort pomocniczy położony w środkowej części stoku w pobliżu Fortu VI Helicha

Fig. 4. A destroyed auxiliary fort located in the central part of the slope near Fort VI Helicha 
(ryc. 4.2). W tym przypadku kształt tych ruin jest owalny (a nie kanciasty), kolisty z łukowatymi ugięciami skierowanymi w dół stoku, czyli jest to kształt bliski naturalnemu ukształtowaniu osuwiska. W takich przypadkach ciężko jest rozróżnić osuwisko od osadów antropogenicznych i wrysować jego dokładną, a jednocześnie poprawną granicę, zwłaszcza jeśli poniżej na stoku mamy rozpoznane osuwiska.

Podobny przykład można spotkać na Prałkowskiej Górze, gdzie znajduje się Fort VII Prałkowce. Prałkowska Góra jest zbudowana $\mathrm{z}$ warstw inoceramowych serii skolskiej, w niektórych otworach wiertniczych ich miąższość dochodzi do $2170 \mathrm{~m}$. Litologicznie sa to piaskowce cienkoi średnioławicowe z łupkami i marglami, przewarstwione łupkami pstrymi, górnej kredy-dolnego paleocenu. Pod warstwami inoceramowymi zostały nawiercone mioceńskie utwory serii złobicko-stebnickiej, wykształcone w postaci mułowców, iłowców piaszczystych, piaskowców i zlepieńców. Na Prałkowskiej Górze warstwy inoceramowe sa miejscami pokryte mułkami lessopodobnymi i glinami eluwialnymi o 10-metrowej miąższości.

W czasie prac terenowych prowadzonych w tym rejonie zaobserwowano, że stok nie dość, że jest mocno osuwiskowy, to dodatkowo jest bardzo przekształcony przez szereg form antropogenicznych, które przenikają i zazębiają się z formami naturalnymi. Na stokach oprócz fortów stałych zaobserwowano różne fortyfikacje ziemne, szańce, wały obronne, suche fosy, ślady walk zbrojnych, a także stare drogi, wyrobiska, kopanki i osuwiska. Rozpoznanie i rozgraniczenie wszystkich form przysporzyło wielu trudności kartograficzno-interpretacyjnych. Pomocne okazało się wykorzystanie NMT wykonanego dla Prałkowskiej Góry, którego fragment przedstawia rycina 5.1, z wskazanymi kilkoma formami antropogenicznymi. Zaznaczają się tutaj zarówno stare, zarośnięte kamieniołomy i łomiki, jak i wojenne fortyfikacje ziemne (prawdopodobnie ślady walk) i zarośnięte, rozjeżdżone drogi. Trudności się nawarstwiają, gdy elementy i budowle fortu, takie jak np. mury obronne, okopy i inne ziemne fortyfikacje, są wkomponowane w stok o morfologii wypukło-wklęsłej. Trudno jest jednoznacznie stwierdzić, czy morfologia stoku jest wynikiem jego sztucznego przemodelowania w wyniku budowy twierdzy, czy też został on pierwotnie przekształcony przez osuwisko, a następnie wykorzystany do budowy fortyfikacji. Pytania takie często pozostają bez odpowiedzi. Nowe światło rzucają archiwalne, historyczne czy topograficzne mapy oraz fotografie (ryc. 5.2, 5.4).

\section{TRUDNOŚCI ZWIAZANE Z WYSTĘPOWANIEM KAMIENIOLOMÓW}

Największych trudności podczas prowadzenia prac kartograficznych dostarczają stare kamieniołomy i wyrobiska, których ślady zachowały się w terenie (ryc. 6 i 7), a które są związane z Twierdzą Przemyśl. Do budowy samej twierdzy wykorzystano niewielkie ilości kamienia lokalnego, ponieważ materiał transportowano z Austrii, Ukrainy i Bieszczadów, to $z$ tych najstarszych wyrobisk pozyskiwano kamień do rozbudowy galicyjskiego XIX-wiecznego Przemyśla. Wyrobiska bardziej współczesne dostarczały wapna palonego i materiałów do rozbudowy miasta i dróg lokalnych w XX w.

Dobrym przykładem są tutaj trzy duże kamieniołomy zlokalizowane na wzniesieniu Kruhel Wielki w południo- wo-zachodniej części Przemyśla, na północnych stokach Wapielnicy. W 1876 r. w tym miejscu została odkryta przez Niedźwiedzkiego skałka egzotykowa wapienia jasnobeżowego, detrytycznego, typu Sztramberskiego. Pierwotnie uważano ją za rafową skałkę tytońską występującą in situ, była i nadal jest ona obiektem zainteresowania naukowców (Wójcik, 1904, 1907, 1913; Niedźwiedzki, 1908; Zuber, 1909; Bukowy, Geroch, 1957; Ney, 1957b; Morycowa, 1964, 1979, 1988, 2008; Geroch, Morycowa, 1966; Liszka, Geroch, 1979; Geroch i in., 1988; Olszewska $\mathrm{i}$ in., 2009) i budowniczych. Tak zwana skałka z Kruhela Wielkiego tkwiła w postaci olistolitów w warstwach inoceramowych serii skolskiej wieku późnej kredy-paleocenu. Tkwiła, ponieważ do dzisiaj została praktycznie wyeksploatowana, a zachowały się po niej jedynie stare kamieniołomy na Kruhelu Wielkim, fotografie i badania naukowe $\mathrm{z}$ ubiegłego stulecia.

Kamieniołom nr 1 z na rycinie 6.3 to przykład starego kamieniołomu położonego na północ od osuwiska o ID 51313 (Baza SOPO). Wyznaczenie granic osuwiska na tym terenie i odróżnienie ich od elementów wyrobiska było wyjątkowo trudne. Na NMT (ryc. 6.3, 6.5) widać doskonale, że formy w obrębie wyrobiska są nawet wyraźniejsze niż formy wewnątrzosuwiskowe, które akurat w tym miejscu są bardzo łagodne. Podobne formy (morfologiczne) obserwujemy w kamieniołomie nr 3 (ryc. 6.4). Oddzielenie form osuwiskowych od antropogenicznych form starej kopalni zajęło autorce wiele godzin obserwacji terenowych. Kształt koluwialnych form wypukło-wklęsłych zależy głównie od rodzaju skał podłoża. Naturalne formy osuwiskowe, rozwinięte na warstwach inoceramowych lub inoceramowych z pokrywą lessową, mają na ogół łagodnie zarysowane elementy wypukłe, które w sposób naturalny, subtelny i ciagły przechodzą w różnego rodzaju elementy wklęsłe. Obraz ten może zaburzyć wyraźna skarpa wtórna, odcinająca się w terenie wyraźnym, ostym i stromo nachylonym progiem. Natomiast kamieniołomy i stare wyrobiska, praktycznie niezależnie od litologii podłoża, często mają bardzo wyraźny, ostry relief, a formy wypukło-wklęsłe są rozłożone dosyć chaotycznie i nienaturalnie. Formy wypukłe mają postać stożków, które często nakładają się na siebie. Natomiast formy wklęsłe są głębokie, z dnem w kształcie rowu, rzadko przechodzą w formy wypukłe w sposób ciągły, liniowy, a częściej są rozmieszczone względem siebie w sposób chaotyczny. Punktowym, owalnym zagłębieniom towarzyszą często podłużne wały akumulacji urobku albo wysokie, hałdy usypane tuż przy zagłębieniu. Natomiast formy osuwiskowe mają bardziej łagodne ukształtowanie, które rozkłada się w sposób ciagły i równomierny na osuwającym się stoku.

W kamieniołomach, które zaczynają się stromą ścianą, poniżej na stoku obserwujemy wypłaszczenie z usypanymi niewielkimi hałdami. Obserwując taką formę, ma się nieodparte wrażenie dużego ubytku materiału. Trudniejsze do rozpoznania są kamieniołomy, gdzie poniżej wysokiej, stromej ściany występują wyraźne formy wypukło-wklęsłe. W tym przypadku są one nienaturalnie wysokie lub głębokie i są chaotycznie rozmieszczone, o ostrym reliefie. Czasem pagóry (hałdy) osiągają większe wysokości niż naturalna powierzchnia zbocza obok (ryc. 7, kamieniołom nr 1). Wyrobiska często zaczynają się bez wyraźnej ściany, nieusystematyzowanymi zagłebieniaminagłymi po wybranym materiale (ryc. 7, kamieniołom nr 2). Obecnie 


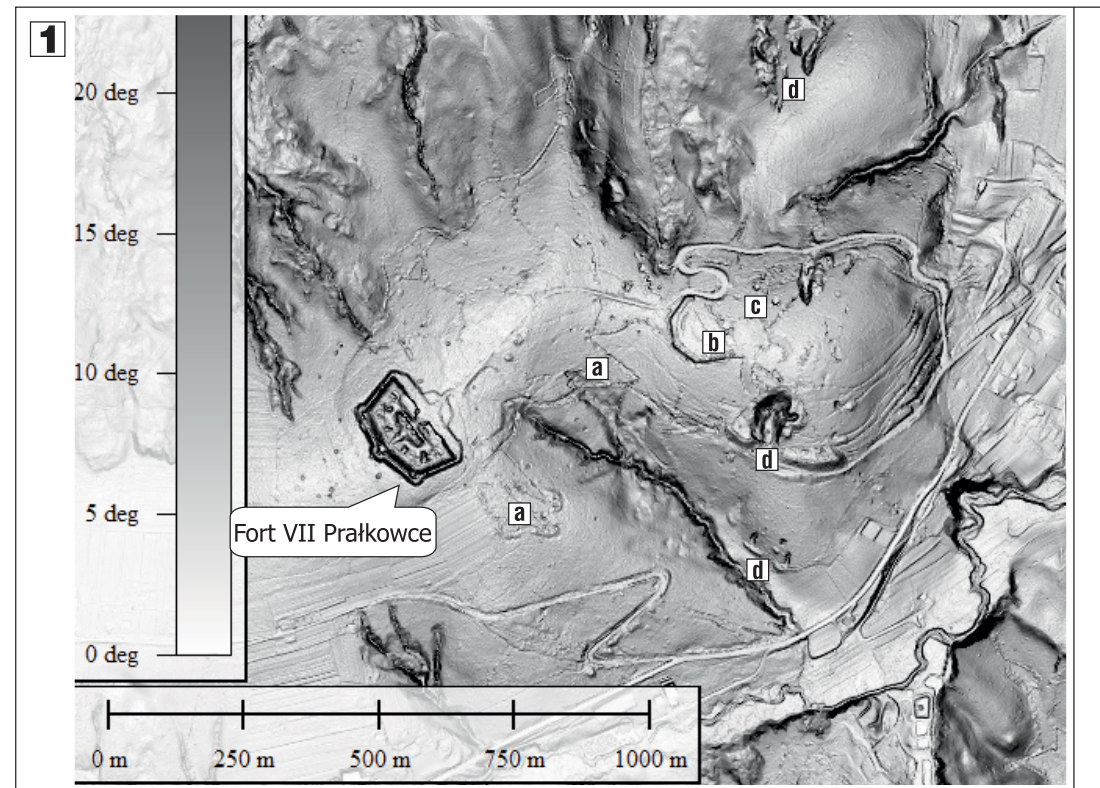
wizualizacja NMT Prałkowskiej Góry
1 z widocznymi elementami atropogenicznymi DEM visualization of the Pratkowska Hill with visible anthropogenic elements archiwalne fotografie

2 przedstawiajace ziemne budowle wojenne archival photos of earth war structures

przypuszczalnie analogiczne miejsca sfotografowane

3 w badanym rejonie w latach 2012-2015 supossed analogous places photographed in the study area in 2012-2015

archiwalna mapa austryjacka z 1903 roku

4 przedstawiajaca rejon Prałkowskiej Góry

archiwal Austrian map from 1903, showing the Prałkowce Hill region

wycinek SMGP ark 1026 Krzywcza dla rejonu badań

5 part of the geological map of Poland, Phet 1026 Krzywcza for the study area
a b okopy
C ślady walk
signs of fights
d kamieniołomy
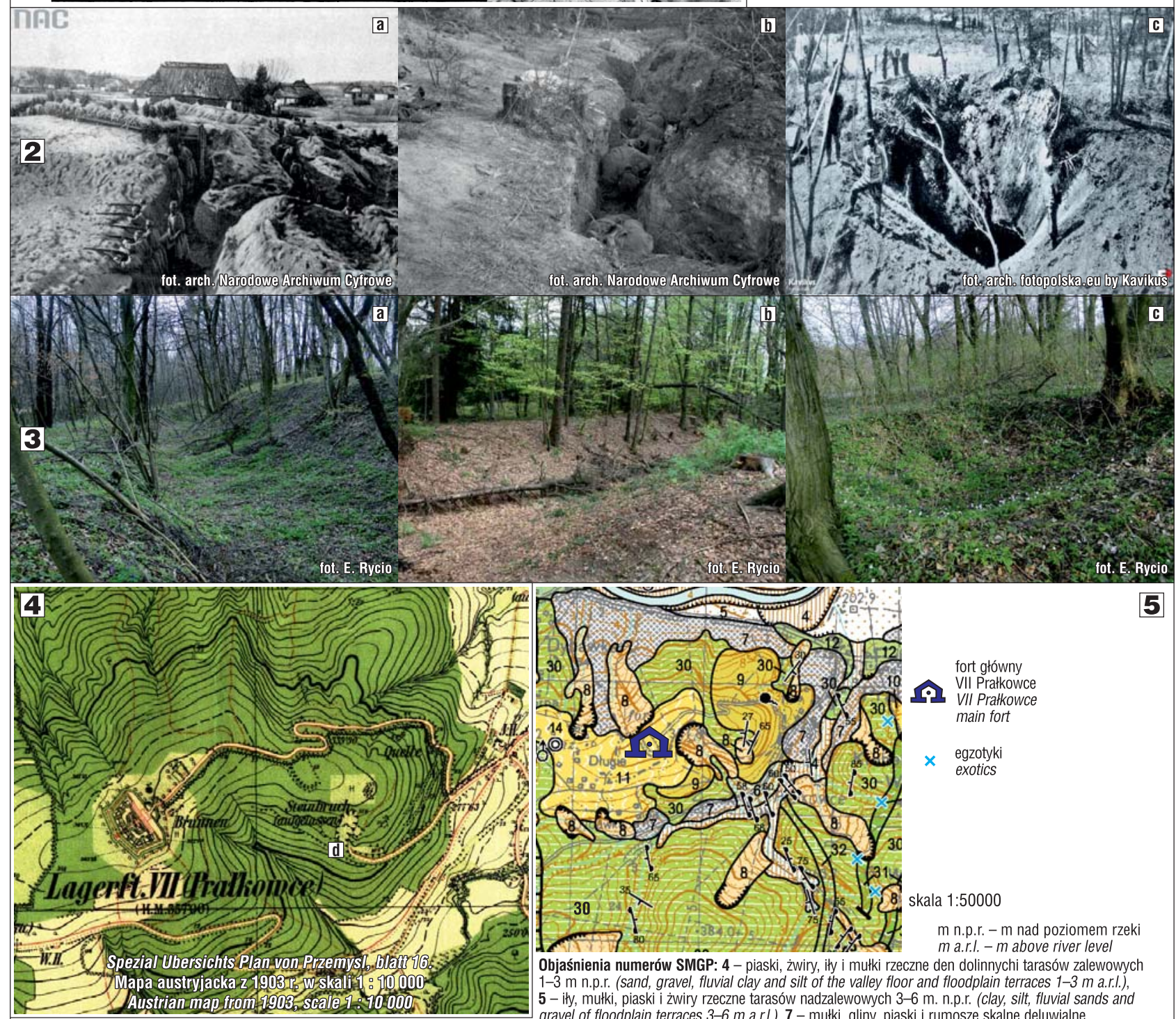

4.13 (deluvial silt, clay, sand and rock rubble), $\mathbf{8}$ - osady koluwialne (colluvial deposits), $\mathbf{9}$ - gliny zwietrzelinowe (eluwialne)(weathered clay, eluvial), 11 - mułki lessopodobne (loess-like silts), (Kgrn/paleocen) wykształcone jako piaskowce cienko- $\mathrm{i}$ średnioławicowe, łupki $\mathrm{z}$ wkładkami margli i łupków pstrych (Inoceramus Beds of the Skole Unit undivided: developed as thinly and medium bedded sandstones, shales with inserts of mudstones and variegated shales [C.up/Paleocene]), 31 - warstwy inoceramowe serii skolskiej (Kgrn) wykształcone jako mułowce z egzotykami i olistolitami wapieni typu sztramberskiego (Inoceramus Beds of the Skole Unit: developed as mudstones with exotics and olistoliths of the Stramberk limestones [C.up]) 32 - warstwy inoceramowe serii skolskiej (Kgrn) wykształcone jako margle z Węgierki (Inoceramus Beds of the Skole Unit: developed as the Węgierka Mudstone [C.up])

Ryc. 5. Pozostałości po Twierdzy Przemyśl i walkach, które zaburzają obraz naturalnej morfologii stoku

Fig. 5. Remnants of the fortress and fights blurring the picture of the natural morphology of the slope 


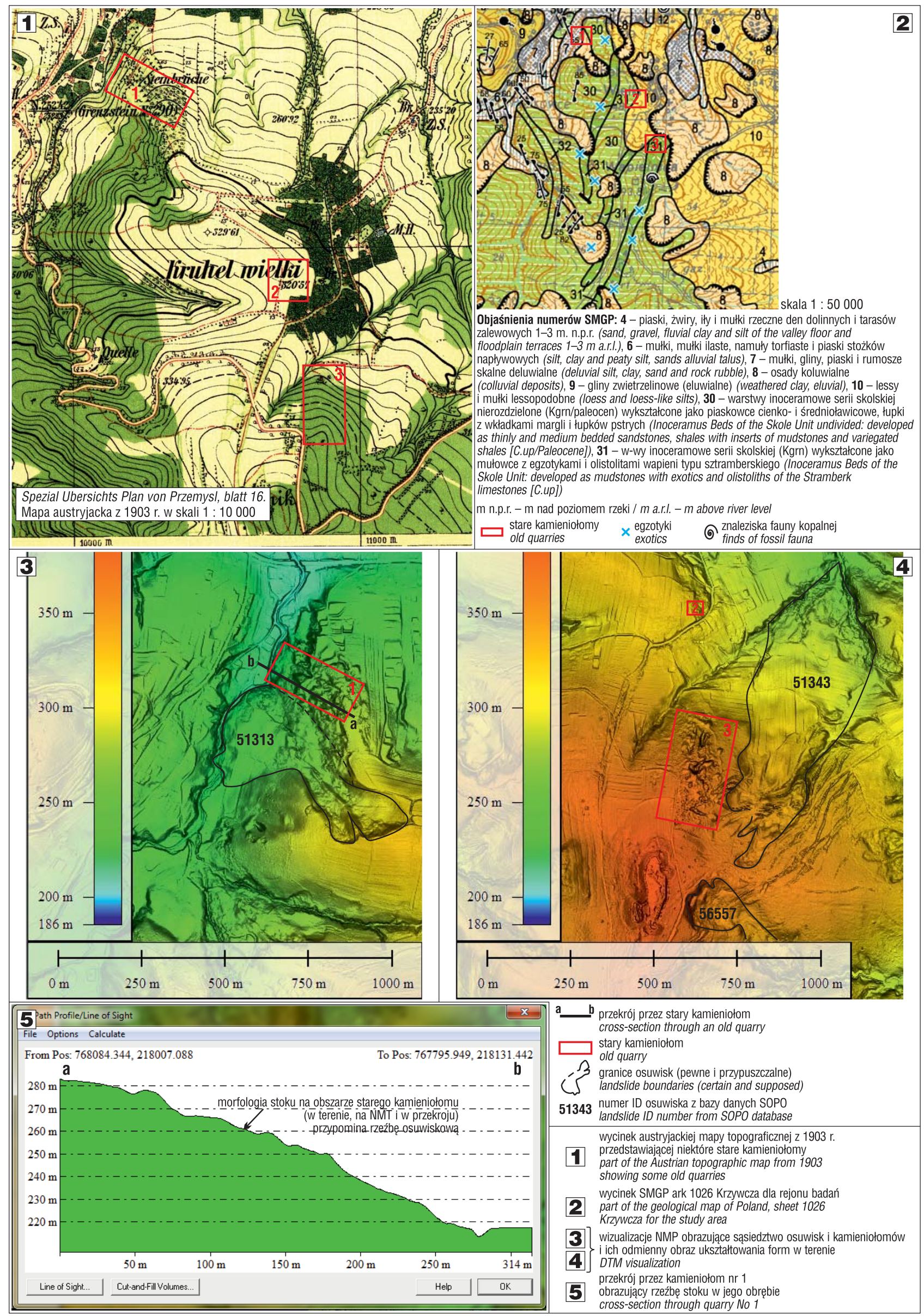

Ryc. 6. Przykłady występowania osuwiska w pobliżu kamieniołomu

Fig. 6. Examples of a landslide occurring near the quarry 


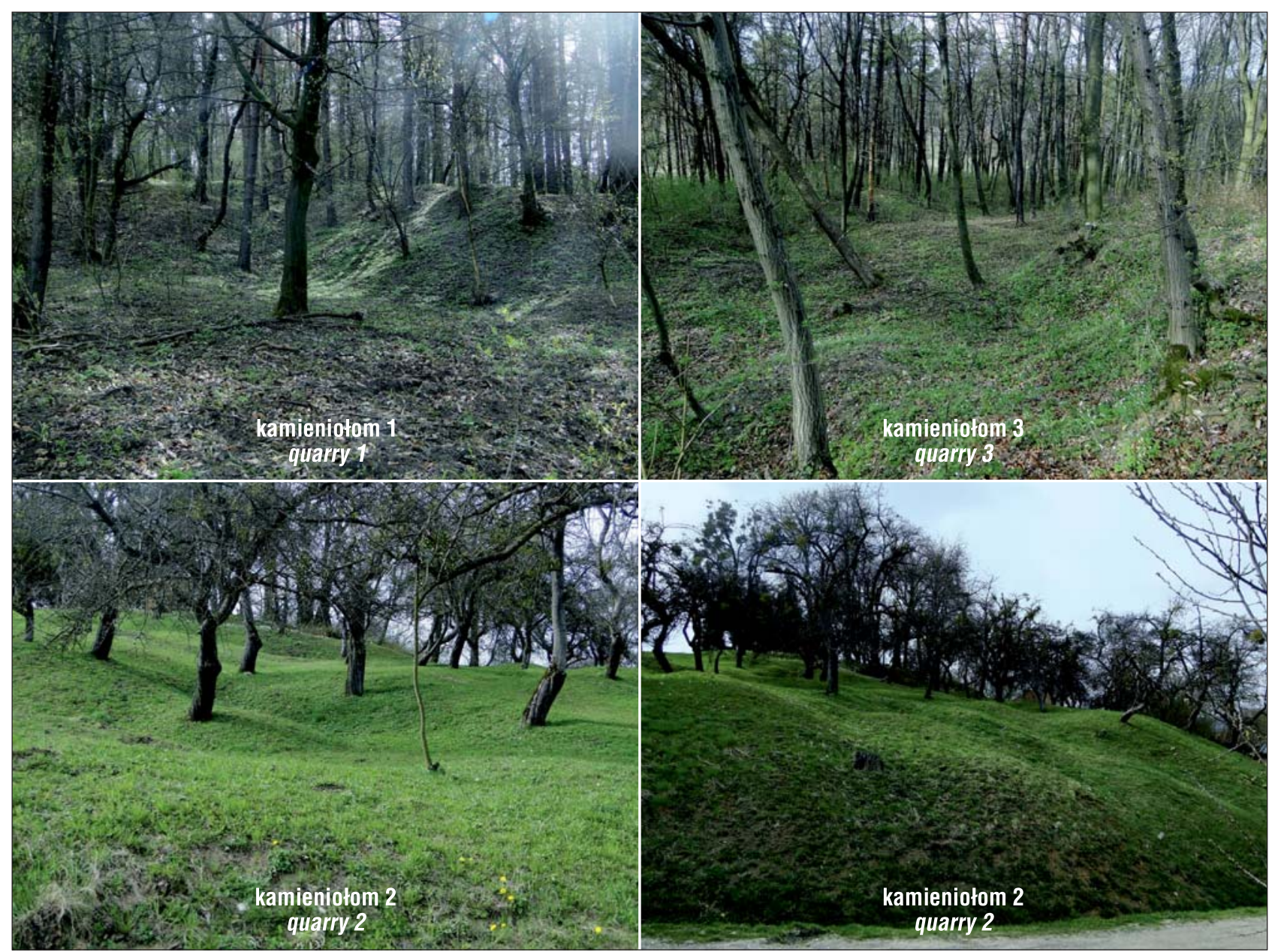

Ryc. 7. Morfologia terenu nieczynnych kamieniołomów z Kruhela Wielkiego

Fig. 7. Elements of the disused quarries of Kruhel Wielki

NMT jest pomocne, zwłaszcza przy niewielkim doświadczeniu terenowym, do interpretacji obiektu jako nieczynny, stary kamieniołom czy oddzieleniu jego granic od naturalnego osuwiska. Właśnie ten ostry relief form, widoczny w terenie oraz na NMT (ryc. 6.3 i 6.4), powinien budzić czujność, wątpliwości i podejrzenia. Wydaje się to oczywiste, jednak błędy w interpretacji zdarzają się bardzo często.

\section{TRUDNOŚCI ZWIĄZANE \\ Z ANTROPOGENICZNYM WYKORZYSTANIEM TERENU}

Trudności w wyznaczaniu osuwisk na badanym obszarze wynikają nie tylko z historii tego regionu i jego budowy geologicznej, ale również ze stopnia zurbanizowania terenu. Silna antropopresja zaciera naturalną morfologię stoków, ograniczając jednocześnie dostępność terenu, co mocno utrudnia prowadzenie obserwacji kartograficznych. Zamknięte osiedla, ogródki działkowe, tereny wojskowe, stoki przekształcone pod budowę: wysypiska śmieci, parku zamkowego, cmentarza miejskiego, nartostrady, to obszary osuwiskowe zmienione do tego stopnia, że bardzo trudno jest dostrzec $\mathrm{w}$ terenie naturalne formy morfologiczne. Idealnym przykładem do omówienia zagadnienia antropopresji jest stok narciarski w Przemyślu, na którym od lat występuje problem odmładzającego się osuwiska (ryc. 8, 9). Nie jest znany dokładny moment jego powstania, ale przyjmuje się, że jest to osuwisko powstałe w holocenie (Rycio,

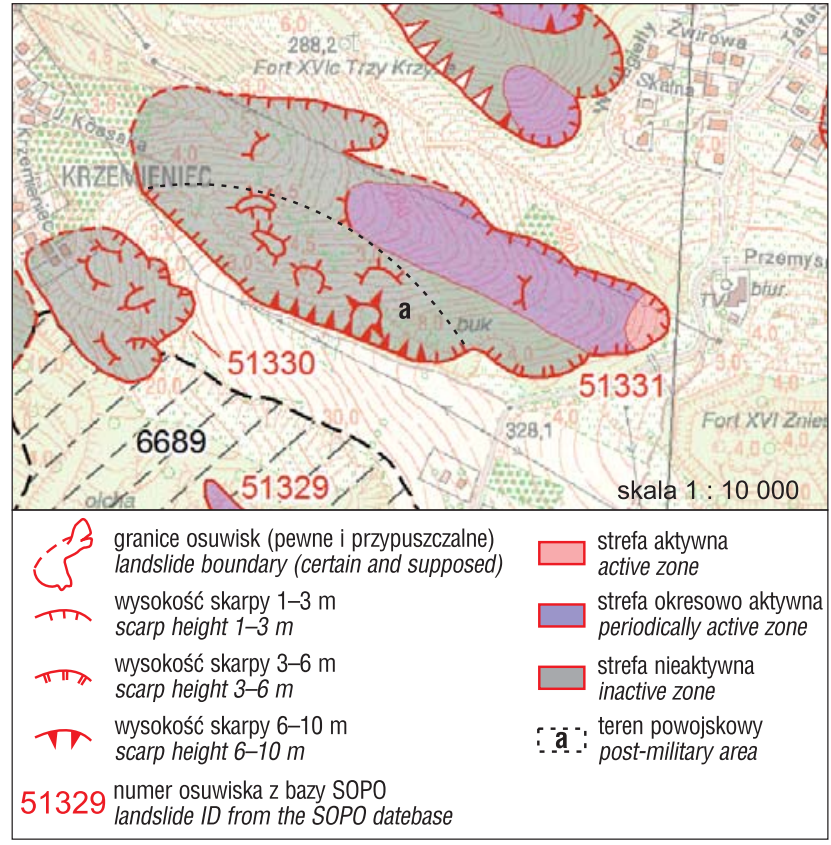

Ryc. 8. Osuwisko na stoku narciarskim w Przemyślu

Fig. 8. Landslide on the ski slope in Przemyśl

2013). W okresach pozornej stabilizacji osuwisko jest praktycznie niewidoczne w terenie, ponieważ stok był wielokrotnie antropogenicznie przekształcany. W XIX w. był częścią poligonu wojskowego, na obszarze którego ćwi- 


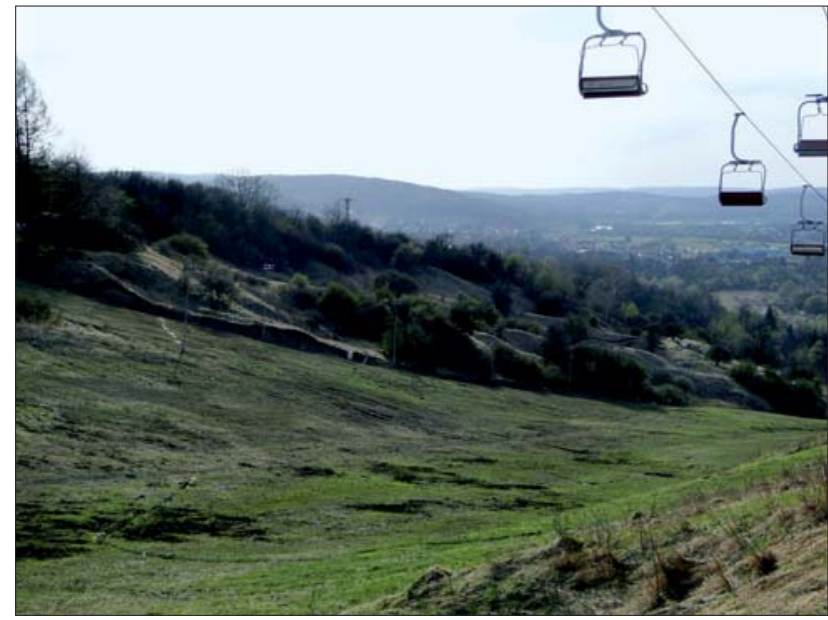

Ryc. 9. Osuwisko na stoku narciarskim w Przemyślu Fig. 9. The landslide on the ski slope in Przemyśl

czono budowę okopów. Przez wiele lat nieużytkowany został w końcu wyznaczony pod budowę wyciągu narciarskiego. Przed rozpoczęciem budowy wykonano dokumentację geologiczną, w której wykazano powierzchnię poślizgu max. na 5,5 m p.p.t. (Ciszkowski, Hałoń, 2005; Gąska, 2011). Po ponownych analizach, badaniach i obserwacjach terenowych $\mathrm{w}$ projekcie budowlanym zmieniono sposób posadowienia podpór kolejki linowej i wykonano infrastrukturę stoku narciarskiego wraz z położeniem technicznych, miejskich kabli przesyłowych. Podczas budowy wyciagu stok został mocno zaburzony. Osuwisko nie zostało zabezpieczone i odpowiednio odwodnione, zostały natomiast zatarte jego naturalne granice. Po raz kolejny skarpa osuwiska odmłodziła się w 2010 r., a następnie w 2013 r. (Rycio, 2013). W maju 2017 r. po 2-tygodniowych opadach osuwisko znów uległo odmłodzeniu, a ziemia osunęła się na samym początku głównej trasy zjazdowej (Borzęcki, 2017). Jęzor ciągnął się na długości ponad 30 m w dół. Lej o głębokości prawie pół metra utworzył się na całej szerokości trasy pod samym szczytem stoku. Miejscami zostały odkryte instalacje elektryczne i światłowodowe oraz rury doprowadzające wodę do sztucznego naśnieżania stoku. Po tym zdarzeniu wykonano doraźne prace zabezpieczające osuwisko. Nie przyniosły one żadnych efektów, bo już na wiosnę 2018 r., po zakończonym sezonie narciarskim, otworzyły się dwie świeże szczeliny w górnej części stoku. Jeszcze w 2017 r. przeprowadzono nowe badania geologiczno-inżynierskie (Bulanda, Czudec, 2017; Madej, 2018; Ziętal, 2018). Na ich podstawie powstał projekt likwidacji osuwiska, który przewidywał zabezpieczenie terenu palami żelbetowymi. W najbliższych latach okaże się, czy prace stabilizacyjne na osuwisku przyniosły zamierzony efekt.

\section{WNIOSKI}

Praktycznie we wszystkich opracowaniach, które poruszają problematykę osuwisk, autorzy sygnalizują problem wyznaczenia i występowania osuwisk powiązany z tektoniką i litologią podłoża. Należy zwrócić uwagę, że historyczne przekształcenia obszaru badań wpływają równie mocno na poprawne wyznaczenie i udokumentowanie osuwiska. Często badacze nie biorą tego aspektu w ogóle pod uwagę, przez co niejednokrotnie zostają popełnione duże błędy interpretacyjne. Niosą one za sobą bardzo poważne konsekwencje, zwłaszcza jeśli dotyczą obszarów zasiedlo- nych. Przed rozpoczęciem prac kartograficznych warto zapoznać się z wszelkimi mapami archiwalnymi analizowanego obszaru oraz zdjęciami lotniczymi sprzed lat. Wpływa to pozytywnie na skuteczność i poprawność interpretacji form występujących w terenie, a trudnych do jednoznacznego określenia genezy. Należy pamiętać, że historia pozostawia trwały ślad w geomorfologii terenu.

Metody badań kartograficznych można rozszerzyć o interpretację NMT, który jest jednym z produktów pozyskanych przez LiDAR w ramach Projektu ISOK. Jednak zarówno podczas prac terenowych, jak i podczas analizy NMT należy się wykazać dużą umiejętnością interpretacji oraz wyobraźnią i posiadać duże doświadczenie kartograficzne. Dobrze, by czynności te wzajemnie się uzupełniały i wspomagały. Przed rozpoczęciem właściwych prac kartograficznych konieczne są prace przygotowawcze, które polegają na analizie archiwalnych opracowań, w tym zapoznanie się $\mathrm{z}$ historią regionu, co w przypadku Twierdzy Przemyśl okazało się zasadne i pomocne, a wręcz niezbędne dla poprawnego wykonania zadania. A przykłady takie można wielokrotnie mnożyć, chociażby: twierdza w Krakowie, Kłodzku czy Srebrnej Górze w Górach Sowich. Należy pamiętać, że na stokach znajdują się tysiące starych i nieczynnych kamieniołomów, które mogą łudząco przypominać osuwiska (ryc. 7).

Uwagę kartografów w terenie powinny zwrócić:

- wszelkie prostoliniowe, podłużne formy zarówno wypukłe, jak i wklęsłe, ciagnące się wzdłuż stoku, albo formy o kanciastych kształtach, występujące niezależnie od morfologii stoku lub intersekcji. Najprawdopodobniej są to formy antropogeniczne rolnicze lub historyczne, militarne lub archeologiczne. W żadnym wypadku nie mogą to być rowy rozpadlinowe, wały akumulacyjne, szczeliny lub skarpy osuwiskowe;

- wszelkie prostoliniowe, podłużne formy, zwłaszcza wypukłe, ciągnące się wzdłuż stoku, zgodnie z jego morfologią lub intersekcją. Najczęściej są to zestromienia lub skarpy strukturalne na stoku, wynikające z odporności skał i sposobu wietrzenia. Jeśli pod takim zestromieniem stok nachylony jest jednostajnie, a jedynym zaburzeniem w rzeźbie są drobne dolinki potoków leja źródłowego, to forma najprawdopodobniej nie ma genezy osuwiskowej;

- wysokie, dobrze zarysowane, wyraźnie odcięte łukowate skarpy, pod którymi brak form wskazujących na grawitacyjne przemieszczenie zwietrzeliny po stoku. Stok pod skarpa jest prosty lub jednostajnie nachylony, często z równoległymi zagłębieniami poniżej takiej skarpy, pozostałościami po starych drogach. Najprawdopodobniej jest to stary kamieniołom. Inną charakterystyczną dla kamieniołomu cechą są chaotycznie rozmieszczone, głębokie zagłębienia ze stromymi ścianami, z płaskim lub ostro wciętym dnem. Obok znajdują się równie chaotycznie rozmieszczone pagóry o stożkowatych, ostrych grzbietach i stromo nachylonych zboczach, jako pozostałość po hałdach materiału poeksploatacyjnego. Ponadto w obrębie takiej sztucznej formy mogą występować wyraźne, równoległe do siebie ułożone skarpy, bez wypukło-wklęsłych form między nimi. To kolejne ściany i poziomy poeksploatacyjne;

łagodne, wyraźne i dobrze zarysowane formy wypukło-wklęsłe, bez ostrego reliefu występujących form, jak na ryc. 7 dla kamieniołomu 2. Formy na Kruhelu Wielkim łudząco przypominające koluwia osuwiskowe nie są od góry ograniczone żadną regularną linią, która mogłaby być skarpą główną. Nie ma w terenie żadnego progu ani 
linii odcięcia form od normalnego stoku. Formy występują w obszarze stoku górnego, prawie na jego grzbiecie, zaczynają się i kończą przypadkowo rozmieszczonymi pagórkami lub zagłębieniami. Kamieniołom nr 2 na Kruhelu Wielkim byłby niemożliwy do poprawnej interpretacji, gdyby nie znajomość geologii i historii badanego terenu;

- czasem w obszarze starych kamieniołomów, ruin budowli historycznych, militarnych lub archeologicznych, na terenie starych cmentarzysk, grodów lub innych antropogenicznych form znajdują się w terenie różnego rodzaju tablice informacyjne, krzyże, kopce czy inne konstrukcje mające upamiętnić przeszłość danego miejsca.

Wszystkie te wskazówki wydają się być oczywiste, jednak często są one bagatelizowane, co prowadzi do niedopuszczalnych błędów. A niniejszy artykuł ma za zadanie kolejny raz zwrócić uwagę na ten ciągle aktualny problem.

Bardzo dziękuję recenzentom, Panom: Jędrzejowi Wierzbickiemu i Henrykowi Woźniakowi, za poświęcony czas oraz za wnikliwe, krytyczne i konstruktywne uwagi, które przyczyniły się do poprawy jakości artykułu.

\section{LITERATURA}

ALEKSANDROWICZ S.W. 1965 - Rozwój zapadliska przedkarpackiego w świetle wyników badań nad stratygrafią miocenu Polski południowej. Geof., Geol. Naft., 7-9 (103-105): 243-247.

BATOR J. 2005 - Wojna galicyjska. Działania armii austro-węgierskiej na froncie północnym (galicyjskim) w latach 1914-1915. Libron, Kraków. BOBER L. 1985 - Mapa osuwiskowości polskich Karpat fliszowych skala 1 : 200 000. Państw. Inst. Geol. Oddz. Karpacki.

BOBER L. 1990 - Monografia osuwisk karpackich. Państw. Inst. Geol. Oddz. Karpacki.

BORYSŁAWSKI A., GUCIK S., PAUL Z., ŚLACZKA A., WÓJCIK A., ŻYTKO K. 1979 - Mapa Geologiczna Polski w skali 1 : 200 000. Arkusz Przemyśl-Kalników. A - Mapa Utworów Powierzchniowych. Wyd. Geo1.

BORZĘCKI J. 2017 - Czy uda się zabezpieczyć osuwisko? Problem na stoku narciarskim. TVP3 Rzeszów. https://rzeszow.tvp.pl

BULANDA J., CZUDEC G. 2017 - Projekt robót geologicznych na rozpoznanie warunków geologiczno-inżynierskich dla potrzeb opracowania koncepcji zabezpieczenia osuwiska na terenie stoku narciarskiego w rejonie ulicy Pasteura w Przemyślu. GEOTECH Sp. z o.o. Rzeszów. BUKOWY S., GEROCH S. 1957 - O wieku zlepieńców egzotykowych w Kruhelu Wielkim. Rocz. PTG, 26 (4): 297-334.

BURZYŃSKA J. 2002 - Twierdza Przemyśl w okresie I wojny światowej. Przemyśl.

CHOWANIEC J., KOLASA K., NAWROCKA D., WITEK K.,

WYKOWSKI A. 1975 - Katalog Osuwisk. Województwo Przemyskie wraz z zestawem map podstawowych i zbiorczych w skali 1 : 100000 . Nar. Arch. Geol. Państw. Inst. Geol., Oddz. Karpacki, Kraków.

CISZKOWSKI B., HAŁOŃ R. 2005 - Dokumentacja geologiczno-inżynierska określająca warunki geologiczno-inżynierskie w rejonie projektowanej nartostrady w Przemyślu. GEO-HAR Przedsiębiorstwo Usługowo-Handlowe. Usługi Geologiczne. Rzeszów.

FORSTNER F. 2000 - Twierdze i zamki obronne w Polsce - Twierdza Przemyśl. Warszawa.

GARECKA M., OLSZEWSKA B. 1997 - O stratygrafii jednostki stebnickiej w Polsce. Prz. Geol., 45 (8): 793-798.

GARLICKI A. 1973 - Wyniki badań miocenu solonośnego na południe od Przemyśla. Kwart. Geol., 17 (1): 92-105.

GĄSKA P. 2011 - Błąd dokumentowania geologiczno-inżynierskiego i jego skutki dla budowy stoku narciarskiego w Przemyślu. Biul. PIG 446: 49-52.

GEROCH S., GUCIK S., KOTLARCZYK J. 1988 - Pozycja skałek jurajskich Kruhela Wielkiego profilu Formacji z Ropianki(fm). Przewodnik Zjazdowy LIX Zjazdu PTG w Przemyślu.

GEROCH S., MORYCOWA E. 1966 - Przyczynek do znajomości facji i skamieniałości wapienia tytońskiego z Kruhela Wielkiego koło Przemyśla. Rocz. PTG, 36 (3): 295-303.

GŁOWACKI E. 1964 - Aktualny przekrój geologiczny przez jednostkę stebnicka na południe od Przemyśla. Geof. i Geol. Naftowa, 10-12.

GŁOWACKI E., KARNKOWSKI P. 1964 - Warunki akumulacji bituminów w strefie miocenu karpackiego między Przemyślem a Tarnowem. Prz. Geol., 22 (3): 126-129.
GLOWACKI E., JURKIEWICZ H., KARNKOWSKI P. 1966 - Geologia regionu Przemyśla w świetle głębokich wierceń. Kwart. Geol., 10 (1): 211-249.

GUCIK S. 1962 - Budowa geologiczna północnego brzegu jednostki skibowej między Pruchnikiem i Ujkowicami. Kwart. Geol., 6 (4): 794-795. GUCIK S. 1963 - Profil kredy dolnej z okolic Bełwina w Karpatach przemyskich. Kwart. Geol., 7 (2): 257-268.

GUCIK S. 1977 - Rozwój serii menilitowej w skibie brzeżnej Polskich Karpat fliszowych. Kwart. Geol., 21 (4): 940-941.

GUCIK S. 1986a - Szczegółowa Mapa Geologiczna Polski w skali $1: 50$ 000. Akusz Krzywcza (1026). Warszawa.

GUCIK S. 1986b - Objaśnienia do Szczegółowej Mapy Geologicznej Polski w skali 1 : 50 000. Arkusz Krzywcza (1026). Warszawa

GUCIK S. 1986c - Nowe dane o rozwoju paleocenu w jednostce skolskiej Polskich Karpat Zewnętrznych. Kwart. Geol., 30 (2): 408.

GUCIK S., WÓJCIK A. 1980 - Objaśnienia do Mapy Geologicznej Polski 1 : 200 000. Arkusz Przemyśl-Kalników. Nar. Arch. Geol. Państw. Inst. Geol., Warszawa.

GUCIK S., PAUL Z., ŚLĄCZKA K., ŻYTKO K. 1979 - Mapa Geologiczna Polski w skali 1 : 200 000. Arkusz Przemyśl-Kalników. B - Mapa bez utworów czwartorzędowych. Wyd. Geol.

IDZIKOWSKI T. 2008 - Twierdza Przemyśl. Miniprzewodnik. Przemyśl. IDZIKOWSKI T. 2014 - Twierdza Przemyśl. Powstanie - Rozwój Technologie. Krosno.

JABŁOŃSKA B., DRWIŁA S. 1968 - Opracowanie badań sejsmicznych wykonanych w rejonie Radymno - Kaliników - Przemyśl. Nar. Arch. Geol. Państw. Inst. Geol., Kraków.

JUCHA S. 1968 - Utwory paleogenu w głębokich wierceniach w rejonie Przemyśla. Sprawozdanie z Posiedz. Kom. Nauk. PAN, 10 (2).

KARNKOWSKI P. 1997 - The Przemysl sigmoid and possibilities of hydrocarbon exploration. Kwart. Geol., 38 (1): 41-52.

KRZYWIEC P., PIETSCH K. 1996 - Zmienność stylu tektonicznego i warunków sedymentacji na obszarze zapadliska przedkarpackiego między Krakowem a Przemyślem w świetle interpretacji regionalnych profili sejsmicznych. Kwart. AGH, Geologia, 22 (1): 49-59.

KSIĄŻKIEWICZ M. 1972 - Budowa Geologiczna Polski. Tektonika. Cz. 3. Karpaty. Wyd. Geol., Warszawa.

KUŚMIERK J., BARAN U. 2008 - Wgłębna budowa Karpat w strefie sigmoidy przemyskiej: interpretacja profili sejsmicznych i ocen prognoz naftowych. Kwart. AGH, Geologia, 34 (3): 365-384.

LISZKA S., GEROCH S. 1979 - Uwagi o zbiorze mikrofauny K. Wójcika/1903/ z Kruhela Małego koło Przemyśla. Badania paleontologiczne Karpat Przemyskich. Materiały IV Krajowej Konf. Paleontologów. Przemyśl 25-27 czerwca 1979. Kraków.

ŁANCZONT M. 1993 - Warunki akumulacji plejstoceńskich utworów lessowych w dolinie Sanu koło Przemyśla. Kwart. AGH, Geologia, 19 (2). ŁANCZONT M. 1997 - Lessy okolic Przemyśla. Rocz. Przemyski, 33 (4): $3-40$.

MADEJ Ł. 2018 - Przemyśl: likwidacja osuwiska na stoku narciarskim. Geoinżynieria. https://inzynieria.com.

MALATA T. 1996 - Analiza formalnych wydzieleni litostratygraficznych oraz propozycja podziału jednostki skolskiej polskich Karpat fliszowych. Prz. Geol., 44 (5): 509-513.

MARUSZCZAK H. 1988 - Lessy młodsze i starsze w Orzechowcach. Przewodnik LIX Zjazdu PTG w Przemyślu.

MORYCOWA E. 1964 - Korale ze skałki egzotykowej w Kruhelu Wielkim koło Przemyśla (górny Tyton, Karpaty Polskie). Rocz. PTG, 33 (4).

MORYCOWA E. 1979 - Jurajskie i kredowe egzotyki wapienne z Kruhela Wielkiego Koło Przemyśla. Badania paleontologiczne Karpat Przemyskich. Materiały IV Krajowej Konf. Paleontologów. Przemyśl 25-27 czerwca 1979. Kraków.

MORYCOWA E. 1988 - Wapienie egzotykowe typu sztramberskiego z Kruhela Wielkiego koło Przemyśla. Przewodnik Zjazdowy LIX Zjazdu PTG w Przemyślu.

MORYCOWA E. 2008 - Koralowce Scleractinia z wapieni egzotykowych typu sztramberskiego polskich Karpat zewnętrznych. Geologia, 34 (3/1): 129-137.

NEY R. 1957a - O miocenie na przedgórzu Karpat między Przemyślem a Chyrowem. Prz. Geol., 5 (1): 12-18.

NEY R. 1957b - O egzotykach wapieni jurajskich brzeżnej części Karpat i Przedgórza między Sanem a Wiarem. Acta Geol. Pol., 7 (2).

NIEDŹWIEDZKI J. 1901 - Przyczynek do geologii pobrzeża Karpat przemyskich. Kosmos, 26 (244): 538-555.

NIEDŹWIEDZKI J. 1908 - O wapieniu jurajskim koło Przemyśla. Kosmos, 33

NIEDŹWIEDZKI J. 1910 - O wieku warstw występujących na zachodniej stronie Przemyśla. Kosmos, 35.

NOWAK E. 2011 - Mapa morfologiczna miasta Przemyśla w skali 1 : 2000. Usługowy Zakład Fizjografii i Geologii Inżynierskiej. Rzeszów. 
OLSZEWSKA B., PAUL Z., RYŁKO W. 2009 - Pozycja tzw. skałek w profilu jednostek brzeżnych Karpat zewnętrznych. Geologia, 35 (3-1): 93-95.

OSZCZYPKO N. 2001 - Rozwój zapadliska przedkarpackiego w miocenie. Prz. Geol., 49: 717-723.

OSZCZYPKO N. 2006 - Powstanie i rozwój polskiej części zapadliska przedkarpackiego. Prz. Geol., 54: 396-403.

POŁTOWICZ S. 1991 - Miocen strefy karpackiej między Dębicą a Przemyślem. Kwart. AGH, Geologia, 17 (4): 5-27.

POŁTOWICZ S., STARCZEWSKA-POPOW A. 1974 - Rozwój zapadliska przedkarpackiego między Tarnowem a Przemyślem. Rocz. PTG, 42 (4).

ROGALA W. 1921 - Materiały do geologii Karpat cz.I. Nowa górnokredowa fauna z Prałkowiec koło Przemyśla. Kosmos, 46.

ROGALA W., KOKOSZYŃSKA B. 1948 - Rewizja fauny kredowej z Prałkowiec koło Przemyśla. Biul. Państw. Inst. Geol., 42 (za 1947). ROŻAŃSKI J. 1983 - Twierdza Przemyśl. Krajowa Agencja Wydawnicza, Rzeszów.

ROŻAŃSKI J. 2000 - Tajemnice Twierdzy Przemyskiej. San-Set, Przemyśl.

RYCIO E. 2013 - Karta rejestracyjna osuwiska (numer ewidencyjny 18-62-011-51331) w miejscowości Przemyśl. http://geoportal.pgi.gov.$\mathrm{pl} /$ portal/page/portal/SOPO

RYCIO E., CYBULSKA D. 2013a - Mapa osuwisk i terenów zagrożonych ruchami masowymi w skali 1:10 000, gm. Przemyśl Miasto, pow. przemyski, woj. podkarpackie. http://geoportal.pgi.gov.pl/portal/ page/portal/SOPO

RYCIO E., CYBULSKA D. 2013b - Mapa osuwisk i terenów zagrożonych ruchami masowymi w skali 1: 10 000, gm. Przemyśl, pow. przemyski, woj. podkarpackie. http://geoportal.pgi.gov.pl/portal/page/portal/SOPO

RYCIO E., CYBULSKA D. 2013c - Objaśnienia do mapy osuwisk i terenów zagrożonych ruchami masowymi w skali 1 : 10 000,gm. Przemyśl Miasto, pow. przemyski, woj. podkarpackie. http://geoportal.pgi.gov.pl/portal/page/portal/SOPO

RYCIO E., CYBULSKA D. 2013 d - Objaśnienia do mapy osuwisk i terenów zagrożonych ruchami masowymi w skali 1 : 10 000, gm. Przemyśl pow. przemyski, woj. podkarpackie. http://geoportal.pgi.gov.pl/portal/page/portal/SOPO

SKOMPSKI S. 1990 - Plejstoceńskie ślimaki lądowe ze stanowiska Łuczyce k. Przemyśla. Prz. Geol., 38 (12): 546.

STRZEPKA J. 1975 - Plankton starszego miocenu jednostki stebnickiej w okolicach Przemyśla. Nar. Arch. Geol. Państw. Inst. Geol., Kraków. WIELICZKO M. 1992 - Walki w okolicach Twierdzy Przemyskiej w latach 1914-1915 na łamach prasy polskiej. Przemyśl

WILCZYŃSKI Z. 1961 - Nasunięcie stebnickie w okolicy Przemyśla i jego element fliszowy. Nafta, 9: 241-245.

WIŚNIOWSKI T. 1918 - Fauna małżów górnej kredy karpackiej w okolicy Przemyśla. Kosmos, 43/44.

WÓJCIK A., RACZKOWSKI W. 2018 - Szczegółowa Mapa Geologiczna Polski w skali 1 : 50 000. Arkusz Przemyśl (1027). Państw. Inst. Geol., Warszawa.

WOJCIK K. 1904 - Dolnooligoceńska fauna Kruhela Małego pod Przemyślem. Rozpr. AU, 42.

WÓJCIK K. 1907 - Exotica fliszowe Kruhela Wielkiego koło Przemyśla. Spraw. Kom. Fizyogr. PAU, 42.

WÓJCIK K. 1913 - Jura Kruhela Wielkiego pod Przemyślem. Rozpr. AU, 53/54.

ZIELIŃSKI J. 1963 - Odkrycie fliszowego fałdu wgłębnego w rejonie Przemyśla i wnioski stąd płynące. Rocz. PTG, 33 (1-3).

ZIETAL N. 2018 - W Przemyślu likwidują osuwisko na stoku narciarskim. Wzniesienie wzmacniane jest żelbetowymi palami. https://nowiny24.pl

ZIĘTARA T. 1991 - Influence of geological structure on landslide development in the eastern part of the Flysch Carpathians. Folia Geographica, Series Geographica - Physica 22: 71-86.

ZUBER R. 1909 - Skałka tytońska w Kruhelu Wielkim koło Przemyśla. Kosmos, 53.

ŻYTKO K. 1986 - Podłoże Karpat na południe od Przemyśla a problem fałdów wgłębnych w Polsce. Kwart. Geol., 33 (2): 364-365.

Praca wpłynęła do redakcji 21.01.2020 r.

Akceptowano do druku 15.09.2020 r. 